\title{
COMMUNICATIVE COMPETENCE \\ AS A CONDITION AND CONSEQUENCE OF SPIRITUAL- CREATIVE DEVELOPMENT OF FUTURE EDUCATORS
}

\section{Victoria Galchenko ${ }^{1}$ \\ Svitlana Repetiy ${ }^{2}$}

DOI: https://doi.org/10.30525/978-9934-588-15-0-119

\begin{abstract}
A subject-matter of the study is the communicative competence of future teachers in its close relationship with the spiritualcreative development of the personality of a student specializing in preschool education. Theoretical analysis of the philosophical and psychological-pedagogical literature was carried out, the curricula of students of qualification "Preschool education" were analyzed, systematic observation of the communicative competence of students during the training sessions and creative competitions, cultural and educational events was accomplished. The purpose of the study is to substantiate theoretically a phenomenon of communicative competence as a structural element of professional culture of a future teacher and to uncover the relationship of communicative competence with the spiritual-creative development of future preschool educators. It is proved that professional culture of a future teacher consists of spiritual wealth (high moral values), a distinct creative personality, ready and able to innovations and transformations; special personal qualities (humanism, unconditional love for children, themselves and other people, pedagogical optimism, tolerance, tact, etc.); knowledge, skills and pedagogical practices in the field of preschool education; external aesthetic appeal. The components of professional culture of future preschool educators are identified, the communicative competence being one of them. We have come up with
\end{abstract}

\footnotetext{
${ }^{1}$ Candidate of Psychological Sciences,

Associate Professor of the Department of Pedagogy and Psychology

of Preschool Education and Child Creativity,

Drahomanov National Pedagogical University, Ukraine

${ }^{2}$ Candidate of Psychological Sciences, Doctoral Student,

Department of Philosophical Anthropology and Cultural Studies,

Drahomanov National Pedagogical University, Ukraine

(C) Victoria Galchenko, Svitlana Repetiy
} 
our own definition of communicative competence of future educators, which is that the communicative competence of a future preschool teacher is the ability to organize co-operative activity focused on the dialogic communication with pupils on the basis of humanistic principles such as love, mutual respect, freedom of creativity with focus on a child's personality aimed at successful socialization of the latter. In the course of the study, it was found that an educator with the developed component of spirituality - spiritual communication - talks with the pupils and other people in a friendly manner, showing unconditional love, keeping in mind linguistic nature of the genetic apparatus, which has a spiritual component. The article also presents a structure of spirituality of a person, namely, a spiritual self, which is an integral combination of the following components: spiritual self-awareness, spiritual orientation, spiritual traits, spiritual creativity, spiritual communication, and spiritual experience. A particular attention is paid to the concept of spiritual creativity, the essence of which is to understand that the cause of any situation lies in the spiritual dimension, and its consequence - in the physical one. The article describes the structural components of creative potential of a future teacher, among them are the following: openness to the new, value orientations, freedom of choice, critical thinking, intuition, readiness for constant self-development and self-actualization, creativity, communicative competence, etc. It is proved that in order to increase the level of speech competence of future preschool teachers, it is necessary to intensify the creative-speech activity of students specializing in preschool education, namely: to strengthen the conversational orientation of specialized courses, educational, cultural-leisure activities, and the tasks of practical training. The article also presents our own concept of "spiritualcreative development of the personality of a future teacher": spiritualcreative development consists of qualitative changes that occur in the mind of a future specialist in the process of communication, training, selfeducation and various activities, and lead to the development of new sides of the mentality such as unconditional love, expansion of consciousness, humanistic outlook, freedom of choice, optimism, and high creative potential. It was established that the communicative competence of a future teacher is both a condition and a consequence of his/her spiritualcreative development. 


\section{Introduction}

The crisis of today has affected almost all areas of human life. Youth have experienced the most difficulties in the spiritual, socio-economic, ideological spheres of the country. The signs of spiritual crisis are: growing indifference, alienation, loss of spiritual values, lack of faith in oneself and desire for self-knowledge, self-perfection and realization of creative potential. Education is connected with all the processes that take place in the Ukrainian society. Only high-spirited, creative, dialogue-oriented individuals are capable of establishing effective communication in various areas of life and can lead a country out of a deep crisis. In this regard the requirements for education and a teacher as a carrier of spirituality, which imparts spiritual values to a younger generation in the process of establishing a constant dialogue by means of communicative activity, have greatly increased.

Hence, we believe that future educators of a preschool education institutions should have a high professional level of the communicative competence, as they deal with theyoungestmembers of society-preschoolers, whose proper upbringing depends on the further progress of our state. In addition, the task of an educator is not only to carry out the educational process, but also to focus on their own spiritual-creative development and self-improvement throughout the life, since only a high-spirited creative teacher can bring up an identical personality.

\section{Analysis of recent researches and publications}

The problem of spirituality of a person, their consciousness and speech is covered both in the works of ancient philosophers, sages and modern scholars-philosophers, educators and psychologists such as St. Augustin, L. Vygotsky, M. Golets, V. Humboldt, S. Groff, Quintilian, S. Krylova, O. Luria, I. Melikov, N. Pavlyk, E. Pomytkin, O. Potebnia, V. Suhomlynsky, N. Khamitov, et al.

The conducted analysis of philosophical, psychological and pedagogical views on the phenomenon of spirituality led to the conclusion that spirituality is considered as a defining characteristic of a person (M. Berdyaev, N. Karaulna, A. Komarov, G. Skovoroda, A. Sokolov, et al), the fullness of being oriented by spirit (V. Baranovsky, M. Gorlach, V. Kremen, S. Krymsky, V. Rybalko, et al), a complex system including formations 
of consciousness, self-consciousness, which reflects needs, values, moral orientations (V. Andrushchenko, I. Bech, K. Zhurba, O. Oleksiuk, et al). Scientists consider that one of the signs of the spirituality of a person is awareness of person of themselves as a part of the Universe, which leads to self-knowledge, self-improvement and creativity (V. Vernadsky, V. Plykin, E. Pomytkin, A. Cherniy, I. Shvaneva, J. Yuzvak, et al).

The process of spiritual development of an individual, including a teacher, occurs through self-discovery and improvement of the intimate qualities and formation of a professional culture, communicative competence being one of its indicators.

Many psychologists and psycholinguists such as B. Ananiev, M. Bakhtin, L. Vygotsky, M. Zhinkin, I. Zimnya, V. Krasnykh, B. Norman, O. Potebnya and others have devoted their studies to the problem of formation of communicative competence.

Modern linguistic guides (A. Bogush, E. Yegorova, L. Kalmykova, I. Lutsenko, A. Nikitina, T. Symonenko et al.) consider the content of communicative competence as part of a competent approach to the language learning.

Therefore, the development of a teacher's spirituality is due to the increase of their spiritual and professional culture - a system of views and beliefs, which become obvious in the process of communication of the subjects of educational process and manifest themselves in the attitude towards oneself and people around them.

\section{Identifying the goals of the article}

The purpose of this study is to substantiate theoretically the phenomenon of communicative competence as a structural element of the professional culture of a future teacher and to uncover the relation between the communicative competence and spiritual-creative development of future preschool educators.

Theoretical analysis of the philosophical and psychologicalpedagogical literature was carried out, the curricula of students of qualification "Preschool education" were analyzed, systematic observation of the communicative competence of students during the training sessions and creative competitions, cultural and educational events was accomplished. 


\section{The study results of the professional culture of a future educator}

Based on the theoretical analysis of the philosophical and psychologicalpedagogical literature, we have found out that spiritual potential is given to a person from birth, therefore, during their higher education studies a future teacher should turn their life into life-creation, by which we mean the improvement of intimate qualities, enhancement of professional culture, which is reflected in relevant behavioural acts.

In our opinion, professional culture of a future teacher consists of spiritual wealth (high moral values), a distinct creative personality, ready and able to introduce innovations and transformations; special personal qualities (humanism, unconditional love for children, themselves and other people, pedagogical optimism, tolerance, tact, etc.); knowledge, skills and pedagogical practices in the field of preschool education; external aesthetic appeal (V. Galchenko).

Therefore, the professional culture of future preschool teachers is a multi-level and integrated entity that includes such components as:

- moral-ethical (high spiritual development of a person; their social attitude, values, principles and ability to reflect);

- motivational (a personal attitude of a future specialist to the chosen profession, identification of its place in the general structure of professions, determination of a leading motivation in the work of the educator - humane attitude to a child, belief in their strength and abilities);

- cognitive (a proactive attitude to cognitive activity, effort to fully understand the core of the profession of preschool teacher);

- emotionally determined (a high interest and persistent desire to find out more about the profession of a teacher of preschool education, strongwilled and stable orientation to carrying out a professional activity in the field of preschool education);

- personality-creative (a high level of creativity, ability to self-regulation and self-development, pre-formed life strategies, goals, plans, projects, skills of life-creation as leading characteristics of creative personality).

- instrumental (a high level of general culture, life experience, knowledge, skills and abilities of a professional activity acquired in a higher educational establishment, communicative competence) [6, p. 115].

Therefore, the components of the professional culture of future preschool teachers that we have identified, the need for the development 
of spiritual and creative potential require the setting of special tasks for the training of pedagogical personnel in the system of modern higher pedagogical education. Training of such specialists should be based not only on the development of professional skills but also on the establishment of a humanistic basis for the personality of a future preschool teacher, the development of their spiritual, creative potential, aimed at improving their own intimate qualities and qualities of their pupils.

\section{Research on communicative competence as one of the components of professional culture}

The communicative competence is an extremely important indicator of a future educator's instrumental component of the professional culture.

As explained by A. Bohush, I. Lutsenko, the communicative competence is a complex use by a speaker the linguistic and non-linguistic means in order to communicate in specific social and everyday situations, the ability to navigate the communication situation, their initiative, as well as human awareness, a certain system of knowledge and skills, and conversational abilities [4; 14].

The basis of communicative competence is the communicative activity of a teacher, which, according to L. Kalmykova "has great applicability, especially for linguistic methodology, because it gives an idea of different properties of their progress, specific features of their psychophysiological mechanisms, and therefore allows you to organize a learning process aiming it either at the development of spontaneous, unconscious, affective, unintentional, involuntary speech, or at the development of purposeful, intentional, conscious, arbitrary, controlled speech - depending on the didactic purpose and age-specific features of language acquisition and language proficiency of children" [11].

Thus, the communicative competence of a future preschool teacher is an ability to organize co-operative activity focused on dialogic communication with pupils on the basis of humanistic principles such as mutual respect, freedom of creativity, tolerance with a focus on a child's personality aimed at successful socialization of the latter.

A distinctive feature of preschool children is their ability learn a language practically, imitating adults, adopting their language pattern, style and lexical structure. That is why a future educator should master all the 
abundance of language means, enrich their vocabulary range, speak clearly, meaningfully, emotionally and vividly in order to pick up the interest of pupils and share similar speaking skills abilities with them.

To increase a level of the communicative competence of future preschool teachers, it is necessary to intensify the creative-communicative activity of students of qualification "Preschool education", namely: to strengthen the communicative orientation of such educational courses as:

- "Culture of Speech and Expressive Reading",

- "Rhetorics",

- "Ukrainian Language",

- "Ukrainian Culture",

- "Children Literature",

- "Psychology of Children Creativity",

- "Preschool Linguistics",

- "Fundamentals of Fine Arts with Methods of Leadership",

- "Training of Pedagogical Communications",

- "Pedagogical Interaction of Preschool Education Institution with Family",

- "Family Psychological Assistance", etc.

At each of the classes a differentiated approach to students should be used: to identify the causes of speech errors with students, find them in spiritual plans, and introduce methods of overcoming them.

\section{Research on students' spiritual and creative development}

Let's take a closer look at the spiritual-creative development of students of qualification "Preschool education" in relation to their communicative competence.

By summarising the interpretations of a term "spirituality" presented in scientific resources, we consider the psychological-pedagogical essence of the spirituality of an individual as a deep psychological formation - the spiritual self, awareness of which promotes spiritual self-improvement, lifecreation according to the laws of Beauty, Goodness, Truth, development of the feeling of spiritual unity with others as parts of the Universe, based on the need, in our opinion, to focus on the value of the cognitive sphere of the psyche. Based on the personality structure defined by V. Rybalko, we have drawn up the structure of personality spirituality, namely, the spiritual self, 
which is an integral combination of the following components: spiritual self-awareness, spiritual orientation, spiritual character traits, spiritual creativity, spiritual communication, and spiritual experience [19, p. 148].

A philosopher, educator and theologist Ivan Ogienko believed that spirituality includes the formation of consciousness and self-consciousness of a person, which reflects their most important life needs, views, interests, attitude to the surrounding reality and to themselves as an individual.

The concept of consciousness holds a significant place in the researches of many scholars, since all psychological processes are subordinated to the consciousness, the content of which is spirituality.

According to N. Khamitov, consciousness can be directed both to the outside world and to itself, becoming self-consciousness [21, p. 333].

Self-awareness is the separation of an individual themself from the objective world, awareness of their attitude to the world, themself as a person, their own actions, thoughts, feelings, desires, and interests. An important role in the formation of self-consciousness is played by a language, which arises simultaneously with consciousness and reflects it.

According to E. Pomytkin, a spiritual level of human consciousness is characterized by understanding that the Universe is a single organism and the Earth is an integral part of it [18]. Thus, a level of spiritual selfawareness of a person is characterized by awareness of themself and others as unique cells of the Universe, which affects relationships and behaviour, and in particular, a level of development of communicative competence.

An outstanding scientist and philosopher A. Losev noted that if the parts exist only because they reproduce the whole, and the whole is embodied in its separate parts, then it means that each part of the whole affirms itself not only through the reproduction of the whole, but also through the reproduction of other parts. Parts of the whole, according to the scientist, are not only in their whole, but also in one another [13, p. 82]. Therefore, if a person consciously develops at least one component of their spiritual self, then all the components that contribute to the development of spirituality will be involved in this process.

Understanding of a future educator of their own spiritual self, promotes the development of reflection of their intimate qualities and directs them to the perfection, which is reflected in external behaviour, and in particular, in communicative activity. 
As is generally known, in the mental field of a teacher and a child, the field of the teacher, as a formed personality, is dominant. Educators and students being communication partners, have various communicative and intellectual experience. It should be noted that a human language is built on semiotic features. Phonetic connections in the mind of a person contribute to the organization of the lexical system and its functioning in the process of text introduction. Thus, the spiritual orientation of a teacher helps to use the lexical system that promotes the spiritual growth of their own consciousness and, accordingly, the consciousness of the pupils.

Consequently, the empirically entrenched experience of spiritual formation conveyed by an educator by means of words will be perceived by children. In this way a spiritual potential of pupils is developed.

A person is born and develops as an individual in a society, so we assume that the individual consciousness of a person and the social consciousness processes are interconnected and interactive.

So mutual transition between individual and public consciousness takes place in the process of communication. Therefore, a self-perfected personality, in particular a future educator, should mind their thoughts and speech, which are their reflection. As L. Vygotsky point out, "A conscious word is a microcosm of a human consciousness" [5, p. 46].

Value orientation in life affirms a person's spiritual directivity. Values play an important role in the life of both a person and society. The formed hierarchy of a value system of a human is the basis for decision-making and their behaviour. A sense of existence of a man himself lies in their need for the spiritual values, subordinating their life to them.

E. Pomytkin considers that in order to approach an absolute value - the higher Essence in the upbringing a person - one must rely on a system of transcendental values, namely, Faith, Hope, Love, and focus on accomplishing the ideals of Beauty, Good and Truth in everyday life $[18$, p. 83].

Fostering these ideals in children occur during the communication activity that unfolds in the process of interaction between an educator and educatees.

To be able to convey accurately and perfectly the meaning of such complex categories to children, an educator must have a high level of communicative competence. Therefore, if in the course of their studies 
students subordinate their lives to the spiritual values and constantly work on improving the level of their communicative competence as an indicator of communicative culture, then it will contribute to successful pedagogical activity of development of spirituality and communicative abilities of students in the future.

During the development of spiritual orientation of a person, the perception of art, especially the highly artistic, plays an important role. Art forms an integral personality through an aesthetic standard that is manifested in both positive and negative images. The aesthetic perception develops spiritual, intellectual, and communicative features of an individual, shapes their ability to evaluate and express aesthetic judgment.

In our opinion, artistic activity in an institution of preschool education not only forms the outlook of the preschooler, but also develops his speech potential. Therefore, future educators in the process of studying the humanities or courses of aesthetic orientation ("Handicrafts", "Basics of Fine Arts with Methodology", "Pedagogical creativity", etc.), learn to describe their impressions, verbalize feelings and give verbal evaluation of aesthetic expression. All the mentioned above, in turn, enriches the spiritual realm of future educators. By perceiving works of great composers and folk art, classical music, students can experience catharsis, after which a reassessment of values, and being in general, is possible.

It should be noted that a future specialist with developed spiritual and aesthetic needs treats themselves, the nature and others, not as the owner, but as a person who feels the beauty, uniqueness and originality of each essence. Therefore, we can state that the aesthetic education of children is carried out in the process of communication of an educator with children. This is manifested in their communicative abilities and skills, capability to hold a dialogue with the students, humane attitude towards them, which influences the intensity of spiritual and creative development of all participants of the educational process.

In addition to the above mentioned, it was noted that drama theatre effectively contributes to the formation of communicative competence of students of specialty "Preschool Education". It was organized within the annual charity action "Childhood: a step into the future", initiated by the students of specialty "Preschool education" in 2009. For St. Nicholas Day celebration students take part in the staging of fairy tales, and in the process 
of preparation and performance itself they demonstrate communicative skills and creative abilities. In spring, the students have the opportunity to showcase their theatrical abilities and communication skills in the process of communicating with the children from orphanages of Kyiv and Kyiv region.

Spiritual character traits form the next component of personality spirituality.

In philosophy, it is considered that the character, as a set of permanent mental characteristics of a person, depends on their outlook. In other words, orientation of a human activity, attitude to existence depends on moral principles, attitudes, and beliefs. We think that the socio-historical nature of a person's character is manifested in their communicative competence.

In psychology, the character is regarded as a coherent entity that defines its human "Self". According to N. Pavlyk, character traits are a stable form of responding, behaviour, or attitude [17, p. 72]. E. Pomytkin distinguished the following features of the character of a decent, principled person: strictness, frankness in communication, rejection of hypocrisy, slyness, adherence to high moral standards of behaviour, responsibility, diligence, conscience, reliability, inclination for heroism, willingness to risk for the sake of a lofty goal, and patience [18, p. 143].

Such an approach gives grounds to consider the communicative competence of an educator as the ability to navigate the most important virtues of a principled person, to enrich their vocabulary with a list of these virtues and their senses, to use actively the above mentioned categories of morals and to impart them to a rising generation.

Communication is a spiritual need of every individual as a representative of society. As a social phenomenon, communication covers all spheres of life and human activity. The content of communication is the content of human consciousness. Spiritual communication on all levels and in all types involves treating everyone and themselves as a component of a single organism and treating animal and plant worlds as part of that organism. Such attitude promotes the spiritual union with the Other. The uniting power that underlies spiritual communication is unconditional love.

In her thesis, V. Zhulay introduces a concept of "perfect love", which she defines as a highest form and a complete acceptance of another person with their specific identity and promoting their individual growth, creative uncovering and the enrichment of their essence. The scientist points out 
that the phenomenon of love helps to unify (both uniting sexes and a community; such harmony is manifested in the denial of selfishness); to promote productive personality development; to create a sense of security as to the Other through the confidence it entails; to recreate a new quality of interpersonal relationships; to resist the "ego social medias" that enhance the fragmentation of the society [10, p. 150].

Therefore, taking into account mentioned thoughts and statements, we consider love of an individual, in particular that of a future educator, as unconditional, which exists irrespective of anything, to themselves, other people, everything essential and contributes to spiritual union with the Other. An educator filled with unconditional love is able to express this feeling by choosing the appropriate utterances that show a child a warm, friendly, positively coloured emotional attitude with a preschooler personality as a dominant element. All mentioned above are the features of dialogical communication, in which a person is defined as a highest value.

According to W. Humboldt, a speaker and a listener perceive the same object in different ways and read a certain meaning into the same word. Therefore, mutual understanding between the interlocutors is at the same time a misunderstanding [8, p. 233]. The emotional colouring of the word plays an important role in such cases.

An educator with a developed component of spirituality - spiritual communication - speaks to the pupils and other people benevolently, with unconditional love, being mindful of the linguistic nature of the genetic apparatus that has a spiritual component.

\section{Relationship between communicative competence and spiritual-creative development of an individual}

The mutual influence of the development of spirituality of a future educator's personality and their communicative competence is determined by a level of development of the creative component of spirituality.

Contemporary scientists N.V. Hamitov, L.I. Tarasyuk regard creativity as the ability to accomplish tasks on the basis of coming up with new ideas. The authors state, "Creativity of a true creator must change the world, not overflow it with more and more new works" [21, p. 181].

The up-to-date philosophical dictionary states that creativity is a constructive activity for the creation of a new one [7, p. 625]. In the 
era of antiquity, creativity was associated with the creative processes of cosmogenesis and the concept of Eros as a creative goal-setting; in the Middle Ages - with the creative potential of God as Creator; during the Renaissance, creativity was considered as artistic achievements of a man. German classical philosophy focuses on the cognitive aspects of creation; some contemporary philosophers (N. Hartmann, E. Husserl, A. Whitehead) consider creativity a merely intellectual phenomenon; the philosophy of existentialism interprets creativity as an existential phenomenon that underlies the freedom of a personality [7].

In his studies, a world-renowned philosopher M.O. Berdyaev stated that humanity was on the verge of a world religious era of creativity, on the so-called space pass. This creative age must produce a new creative doctrine of a man, of the world and its development. Such a doctrine envisions freedom as the basis of necessity, and personality as the basis of any being. According to the scientist, creative spiritual life is the movement, but a very peculiar movement which is not plane, but vertical, going up and deep down. "Truth and beauty cannot prevail in the triviality of the world, in the wide field of lineal life, they ascend to the cross and only through the mystery of crucifixion does the rose of world life resurrect" [3].

In view of the above, we are convinced that a blossoming creative beginning of a person who will go forward boldly to meet the unknown, freely spreading their wings of creative inspiration, will overcome the life obstacles solving the creative tasks that are set before them, should become this "rose of the world life".

If philosophy deals with the essence of creativity in different historical epochs, then psychology studies two aspects of creativity: first, as a psychological process of creating a new, second, as a set of personality traits that ensure success of this process.

Recalling the role of spirituality in the professional activity of a teacher, it should be noted that the driving force for the development of the creative personality of a future teacher should be a contradiction between the requirements of society to the level of formation of their essential integrative quality and real chances of a personality to satisfy these requirements. The preconditions for the development of a creative potential as a basis of professional culture of a future teacher of preschool education should become the student's abilities, necessity for self-actualization, motivation 
of personal and professional growth, orientation to a certain teacher's ideal, spiritual values that he or she professes, identification with him or her on the basis of presence of particular individual features, a unique style of activity and behaviour that accumulates in the teacher's communicative abilities, his or her communicative competence.

Thus, the interpretation of the concept of spiritual-creative development of the personality of a future teacher can be the following: spiritualcreative development is qualitative changes that occur in the mind of a future specialist in the process of communication, training, self-education and various activities, and they lead to the emergence of such innovations in psyche as unconditional love, expansion of consciousness, humanistic attitude, freedom of choice, optimism, and high creative potential.

In our opinion, therefore, a mission of a person who has chosen the profession of a preschool teacher should be a persistent work on perfection of the spiritual-creative world, both their own and that of their pupils. The life path of an adolescent depends on what values the teacher and parents will inculcate in them, what guidelines will be chosen, what approaches will be used to make a child understand the meaning of his or her life. Pupils gain the vision of the future and their place in it based on their communication experience gained in the childhood, the laid down principles, rules and code of behaviour, by-past reality situations, developed personal attitude to the problems and achievements. That is, a life scenario of a growing personality is created, in which teacher plays the leading role, so the latter should possess an optimistic attitude, a broad outlook, a high level of communicative competence, self-awareness and creativity, an ability to fugle helping the pupils to create themselves by means of a word.

According to M. Berdyaev, the spirit can create, since it is "a creative activity" [2, p. 271] and "a divine element" [2, p. 251]. We are certain that the spirit of a man creates by a word, the mysterious process of communication by means of speech. According to V. Humboldt, speech is a continuous activity of the spirit aimed at transforming a sound into an expression of thought [8, p. 365].

If we consider the category of professionalism of preschool teachers at the level of pedagogical acmeology, we can see that professional activity of a teacher is "a leading way to learning the art of living" (L. Sohan, E. Fromm, et al.). 
As per L. Sohan, in order to enjoy life, it is necessary to perform a spiritual-moral achievement, since there are always difficulties along the way, which, at first, seem insurmountable, but thanks to the art of living, development of your own life strategy, the ability to build an original behaviour model in unpredictable situations, there is always a solution, obstacles are being broken, new horizons are being opened [20].

From our point of view, the art of living is an indicator of the socialpsychological maturity of a person, which is manifested in the ability to communicate on the basis of humanistic psychology.

The humanistic value of developing professionalism is consolidated in the ability of educators to organize their life path as a whole, complying its goals and life values. A. Antypyev points out that the humanization of education lies not only in strengthening of humanness in the relations between subjects of this process, but also in the orientation towards universal values [1, p. 98].

Understanding of professionalism, of course, is possible by realizing the integral components of activity, personality, and communication. Formation of professionalism of teachers of preschool education is impossible without introduction of psychological system of studying and development of communicative competence in the structure of general ability of a student to professional and personal growth. A fundamental characteristic of professionalism of a teacher is also a manifestation of their readiness to accept self-development of a child in the process of mastering their speech as a means of establishing relationships with peers and adults.

We believe that all of the above has its logical reflection in such a concept as life-creating potential of a future teacher of preschool education. Therefore, we have distinguished components of life-creating potential, among which an ability of a teacher to communicate is a keynote. In other words, a communicative competence is one of the basic conditions and consequences of forming a teacher as a professional. From this it follows that the components of a life-creating potential of a future preschool teacher are:

- Openness to the new.

- Value orientations.

- Freedom of choice and namely that of your viewpoints, life strategies, ways and means of mastering socio-cultural experience.

- Critical thinking (the ability to comprehend critically and interpret everything that is happening in life). 
- Intuitiveness as the ability to estimate, make decisions and predictions in the quickest way.

- Willingness to constant self-development and self-actualization.

- Creativity as a general creative ability.

- Communicative competence (a high level standard of speech, an ability to persuade and to tolerantly get an opinion across to listeners, an ability to exert a positive psychological influence on the behaviour of students by means of words).

- Inclination for leadership (the ability to take responsibility for others)

- Social activity.

- Social resourcefulness (the ability to create one's own models of communication and interaction with people).

- Inclination for impunitive (surmounting) behaviour in critical situations.

Thus, by enabling their creative potential and, at the same time, transferring communicative competence to a higher level, a future educator contributes to the development of their own spirituality, the spirituality of children and, accordingly, the Universe. Even the ancient sages said that in order to change the world one needs to change themself.

The essence of spiritual creativity lies in the understanding of the fact that the cause of any situation is in the spiritual body, and its consequence is in the physical body. Settling a problem, making a decision based on a certain thought promotes spiritual self-creation, self-improvement of a person and, as a consequence, productive creative life.

V. Krasnykh, considering the process of socialization of an individual, notes that thinking and knowledge of a person of each generation are not inherited biologically, but are formed during life by assimilation of the culture created by the previous generations. Thus, the experience of a man is generated [12].

Experience as a philosophical category is the integrity and versatility of a human activity, which combines knowledge, skills, feelings, and will.

Spiritual experience is accumulated by an individual in the process of their spiritual life. A person, a future educator, in particular, who consciously embarked on the path of spiritual development, recognizes and perceives the reality from the standpoint of sensation of themselves and others as the cells of the Universe, and all the essence as the involvement with it. This perception contributes to the development of moral-spiritual reflection, the pursuit of the ideals of Beauty, Good and Truth in a daily life, spiritual self- 
creation, self-improvement, a creative approach to professional activity, the development of unconditional love, which is, in fact, a spiritual experience.

It should be mentioned that the human experience is imprinted in consciousness and inherited genetically. The spiritual experience is a mechanism of stabilization, which preserves the process of a person activity, their orientation, internal harmony and harmonious relationships in society.

Thus, the accumulated experience of spiritual self-perfection is a fixed attitude and influences unnoticeably for a person themselves their viewpoints and the level of communicative competence.

To sum up, we can state that the communicative competence of a future preschool teacher is based on their spiritual experience and, as a consequence, they will pass on their spiritual experience to the children by means of creative communicative activity.

\section{Research conclusions and prospects for further studies}

Ith regard to foresaid, we have come to the conclusion that the communicative competence of an individual, their spirituality and creativity are interconnected and equally determine each other. We are convinced that the development of our state requires a future teacher to be an example of the communicative and spiritual culture of the Ukrainian nation. Therefore, at the present stage of the development of a new Ukrainian statehood and organization of the educational process in higher pedagogical institutions special attention should be drawn to communicative competence as a condition and consequence of the spiritualcreative development of future specialists of preschool education.

As a result of the research we have found out the following: firstly, one of the components of the professional culture of a future teacher is their communicative competence; secondly, the communicative competence of a future educator lies in the ability to establish a dialogical, humanistic-oriented communication with pupils, a child with his or her unique inner world self being the center of it; thirdly, unconditional love for children, for themselves and for others should be a main result of the spiritual-creative development of a student of specialty preschool education. All these phenomena are interrelated, and the communicative competence of a future teacher is both a condition and consequence of their spiritual-creative development.

We consider diagnostic study of the level of spiritual-creative development of future preschool teachers as the potential for further scientific researches. 


\section{References:}

1. Antip'ev A.G. (2009). Gumanizatsiya i gumanitarizatsiya obrazovaniya : sostoyanie i problemy [Humanization and humanization of education: state and problems]. Vysshee obrazovanie v Rossii, no. 6, pp. 98-102. (in Russian)

2. Berdyaev N.A. (2003). Dukh i real'nost' [Spirit and reality]. Moscow: AST; Kharkov: Folio. (in Russian)

3. Berdyaev N.A. (2007). Smysl tvorchestva [The meaning of creativity]. [Electronic resource]. Access mode: https://books.google.com.ua/books/about/ Sense of creativity (in Russian)

4. Boghush A.M. (2013). Movlennjevyj komponent doshkiljnoji osvity [The speech component of preschool education ]. Kharkiv: Ranok. (in Ukrainian)

5. Vygotskiy L.S. Myshlenie i rech' [Thinking and speech]. Moscow: Labirint. (in Russian)

6. Ghaljchenko V.M. (2016). Komponenty profesijnoji kuljtury majbutnikh pedaghoghiv doshkiljnoji osvity [Components of the professional culture of future preschool teachers]. Proceedings of the Udoskonalennja informacijno-resursnogho zabezpechennja osvity i nauky $\mathrm{v}$ umovakh jevrointeghraciji (Ukraine, Bila Tserkva, May 26-28, 2016), Bila Tserkva: Instytut ekonomiky ta upravlinnja, 2016, pp. 113-116. (in Ukrainian)

7. Gritsanov A.A. (2007). Noveyshiy filosofskiy slovar [The latest philosophical dictionary]. Minsk: Sovremenniy literator. (in Belarus])

8. Gumbol'dt V. (1984). Izbrannye trudy po obshchemu yazykoznaniyu [Selected Works on General Linguistics]. Moscow. (in Russian)

9. Jeghorova Je.V. (2014). Komunikatyvna kompetentnistj jak skladova psykhologhichnoji ghotovnosti majbutnikh pedaghoghiv do profesijnogho navchannja [Communicative competence as a component of the future teachers' psychological readiness for vocational training]. Proceedings of the Kompetentnisnyj pidkhid v osviti: teoretychni zasady i praktyka realizaciji : materialy metodologh. seminaru (Ukraine, Kyiv, April, 2014). Kyiv: Instytut obdarovanoji dytyny NAPN Ukrajiny, pp. 199-202. (in Ukrainian)

10. Zhulaj V. I. (2003). Ljubov jak socialjna cinnistj osobystosti v suspiljnykh vidnosynakh [Love as a social value of a person in public relations] ( $\mathrm{PhD}$ Thesis), Kyiv. (in Ukrainian)

11. Kalmykova L.O. (2008). Psykhologhija formuvannja movlennjevoji dijaljnosti u ditej doshkiljnogho viku [Tekst]: monoghrafija [Psychology of speech activity formation in preschool children [Text]: monograph]. Kyiv: Feniks. (in Ukrainian)

12. Krasnykh V.V. (2001). Osnovy psikholingvistiki i teorii kommunikatsii: Kurs lektsiy [Fundamentals of Psycholinguistics and Communication Theory: Lecture Course]. Moscow: Gnozis. (in Russian)

13. Losev A. F. (1988). Derzanie dukha [Daring of spirit ]. Moscow: Politizdat. (in Russian)

14. Lucenko I.O. (2013). Teoretyko-metodychni zasady pidghotovky majbutnikh vykhovateliv do orghanizaciji komunikatyvno-movlennjevoji 
dijaljnosti ditej starshogho do- shkiljnogho viku [Theoretical and methodological bases of preparation of future educators for the organization of communicative and speech activity of children of preschool age] (PhD Thesis), Kyiv. (in Ukrainian)

15. Nikitina A.V. (2015). Ukrajinsjka linghvometodyka dlja maghistrantiv:navch.-metod.posib.[UkrainianLinguomethodicsforUndergraduateStudents: A Toolkit]. Starobilsk: Vyd-vo DZ «LNU imeni Tarasa Shevchenka». (in Ukrainian)

16. Sedov K.F. (2004). Obshchaya psikholingvistika: Khrestomatiya. Uchebnoe posobie [General Psycholinguistics: Reader. Tutorial]. Moscow: Labirint. (in Russian)

17. Pavlyk N.V. (2013). Psikhodiagnostika i garmonizatsiya kharaktera lichnosti v yunosheskom vozraste: uch.-met. posobie [Psychodiagnostics and harmonization of personality character in adolescence: a training manual]. Kyiv: Logos. (in Ukrainian)

18. Pomytkin E.O. (1998). Formuvannja dukhovnykh cinnostej starshoklasnykiv u dijaljnosti shkiljnoji psykhologhichnoji sluzhby [Formation of spiritual values of high school students in the activity of school psychological service] (PhD Thesis), Kyiv. (in Ukrainian)

19. Repetij S.T. (2014). Rozvytok dukhovnosti majbutnjogho specialista jak neobkhidna umova jogho profesijnogho zrostannja [Development of the spirituality of the future specialist as a necessary condition for his professional growth]. Visnyk Instytutu rozvytku dytyny : zbirnyk naukovykh pracj [Bulletin of the Institute for Child Development: a collection of scientific papers]. Bulletin of the Institute for Child Development, vol. 33, pp. 147-153. (in Ukrainian)

20. Sokhan' L.V., Golovakha E.I., Anufrieva R.A., Balakireva O.N., Ocheretyanyy V.V. (1995). Psikhologiya zhiznennogo uspekha. Opyt sotsial'nopsikhologicheskogo analiza preodoleniya kriticheskikh situatsiy [The psychology of life success. The experience of socio-psychological analysis of overcoming critical situations]. Kyiv. (in Ukrainian)

21. Khamitov N. (2016). Filosofskaya antropologiya: slovar' [Philosophical Anthropology: Dictionary]. Kyiv: KNT. (in Ukrainian) 